\title{
COST SENSITIVITY OF INTERNATIONAL STUDENTS IN THE LARGEST HUNGARIAN UNIVERSITY CITIES
}

\section{KÁROLY TEPERICS ${ }^{1 *}$, ZSUZSA M. CSÁSZÁR² , GÁBOR CSÜLLÖG ${ }^{3}$, KLÁRA CZIMRE ${ }^{1}$}

Received 5 April 2021, accepted in revised form 12 May 2021

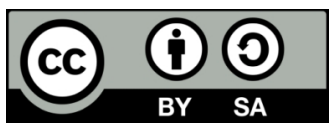

${ }^{1}$ University of Debrecen, Department of Social Geography and Regional Development Planning, Debrecen

${ }^{2}$ University of Pécs, Department of Political Geography and Development and Regional Studies, Pécs

${ }^{3}$ Eötvös Lóránd University, Department of Environmental and Landscape Geography, Budapest

*Email: teperics.karoly@science.unideb.hu

\begin{abstract}
Statistics on international students distinguish between diploma mobility (full-time students abroad) and credit mobility (part-time courses, student exchanges such as Erasmus+, etc.). In terms of economic benefits, their common feature is mostly realised in the spendings by the foreign students in the host country. The comparison of the host cities reveals that Budapest should be considered as a separate category being different from the other cities in many respects. Although, the assessment of the other three university centres (Pécs, Debrecen and Szeged) received similar evaluations (close average values) but some kind of order developed between them in which Szeged and Pécs are perhaps regarded in a little bit more favourable position than Debrecen. There is a lot to be improved to broaden the studentification process in these cities particularly in four fields. The evaluations can certainly be considered useful in the sense that they help to identify those services which are problematic in any terms (price or quality).
\end{abstract}

Keywords: studentification, international students, Erasmus+, Stipendium Hungaricum, feepaying students, costs, accommodation, living, entertainment activities

\section{Introduction}

Statistics on international students distinguish between diploma mobility (fulltime students abroad) and credit mobility (part-time courses, student exchanges such as Erasmus+, etc.). In terms of economic benefits, their common feature is mostly realised in the spendings by the foreign students in the host country. Nevertheless, the amount and period of spending may significantly differ, as credit mobility students typically spend less time (and consequently less money) in the host country.

The process of studentification means that if the number (and ratio) of students on a settlement increases then the local services adapt to their demands over time (Smith 2005). The presence of international students entails countless opportunities for urban development. Students constitute/ represent a considerable purchasing power providing demand for local services in various areas, including catering, 
recreation, transportation, etc. From the aspect of housing (accommodation) it is very important to take into consideration that a significant part of the students live in lodgings (apartments) which, in addition to the apartment rental prices, has a serious impact on the development of real estate prices, too.

According to a research conducted in Szeged (Miklós et al. 2018), exploiting the influence and impacts of international students involves various opportunities for urban development. Students constitute a significant purchasing power, providing demand for local services, whether in the areas of food, recreation, transportation, or other areas. An important element from the aspect of housing (accommodation) is that a significant part of the students lives in sublease which has a serious impact on not only the rental prices but also on real estate prices in general. Social impacts are closely linked to the elements of other dimensions (Universities UK, 2006): the increased rental and house prices can contribute to population change. Students have special needs and require special services, some of which are related to their studies (a classic example is the appearance of photocopying salons), or just as leisure activities (e.g. bars, night clubs), meals (e.g. fast food restaurants). These can form a basis for the establishment/creation of new businesses. The impact of student presence may bring a renewal in the building stock to achieve higher rents, or infrastructure developments related to new services, but it may also cause deterioration of the physical environment and public spaces due to increased traffic and use (Hubbard 2008, 2009). Besides, the urban spatial structure forming power of the leisure activities of students is showing an increasingly globalising character which is also indicated by the newly established services. This can be paralleled with the increasing internationalisation of higher education. (Miklós et al. 2018) Students from different cultures may differ significantly in terms of their consumption habits, use of services, and use of urban space and this may induce differentiated service development. (M. Császár - Wusching 2016)

The study is based on the research entitled "Measuring the economic impacts of inward higher education mobility" whose aim is to measure the local and systemic

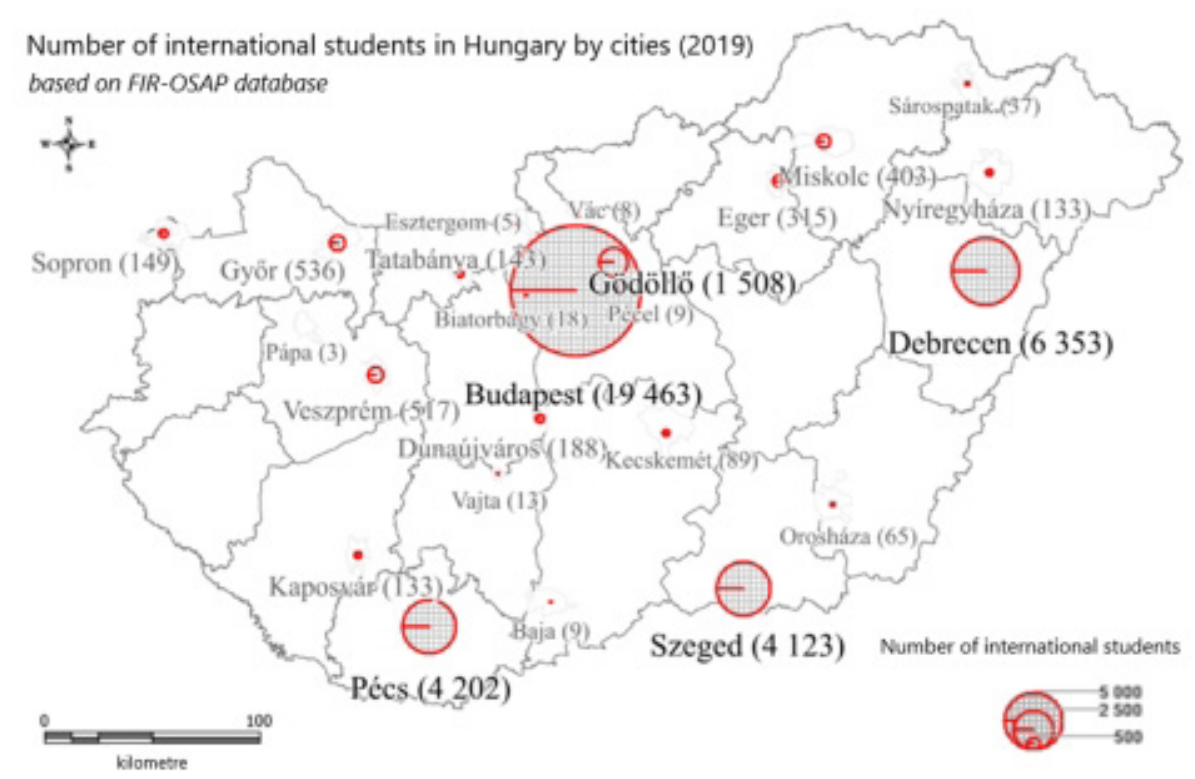

Fig. 1. Number of international students by cities (2019) (Source of data: FIR-OSAP database) 
economic impact of the three target groups of international students (Erasmus+, Stipendium Hungaricum and fee-paying students) in all universities of the country, as well as to analyse their role in tourism and their participation in the studentification process of each university cities. (Fig. 1)

This part of our research focuses on the role of international students in the studentification process in three Hungarian traditional university cities (Debrecen, Pécs and Szeged) and Budapest through the three target groups concentrating on three types of costs (accommodation, living and other/ activities). The four cities selected for the comparison offer similar trainings, and all have high number of students thus they can be regarded as an excellent and reliable basis for the analysis of the studentification processes. The aim of the present paper is to highlight and provide an analysis for the level of satisfaction of the students concerning the costs of various services related offered by the host cities. These reveal differences between the cities and thus allow for conclusions based on financing-consciousness and cost sensitivity of the international students. The results later may serve as a good starting point to find the motives of the international students in their choices of host cities.

\section{Materials and methods}

The mixed methodology applied during the research uses quantitative as well as qualitative data relying on the FIR, KSH, NAV, OPTEN, TeIR and Tempus Public Foundation databases. The students in the Erasmus+ (former Erasmus) and other mobility programmes are available together with those arriving with the aim of obtaining a full degree, and even with the students participating in the cross-border training places of the Hungarian higher education institutions. They and those with (possibly) dual citizenship are considered foreign citizens if their place of birth is outside Hungary. (Berács 2017)

During the analysis, (1) the complete database, (2) the Stipendium Hungaricum scholarship holders, (3) the students participating in credit mobility, and (4) the fee-paying students (typically present in diploma mobility) were processed. In addition to the analysis of the data, we also focused on displaying the data both in terms of numbers (to facilitate the possibilities of secondary analysis) and spatial characteristics. The questionnaire survey (carried out in the first quarter of 2020 - just before the COVID-19 pandemic restrictions were introduced globally) involved the three groups of students for each city. (Table 1)

Regarding the size and distribution of the sample $(18.84 \%$ of the total number of international students), it can be considered reliable in terms of conclusions. In all three target groups 12 training fields were included in the sample, revealing the preferences of each type of international students: more than half of the fee-paying students attend the faculties of medicine (53\%), one-third of Stipendium Hungaricum students chose engineering (33\%), while one-quarter of the Erasmus+/Erasmus students study economics (23\%). The sample truly reflects

Table 1. Geographical distribution of the target groups by types of international students participating in the questionnaire survey $(\mathrm{n}=6296)$ (Subtotal $=$ the four cities, Total = country)

\begin{tabular}{lcccccc}
\hline Target group & Debrecen & Pécs & Szeged & Budapest & Subtotal & Total \\
\hline Erasmus+ students & 16 & 22 & 25 & 289 & 352 & 398 \\
$\begin{array}{l}\text { Stipendium Hungaricum } \\
\text { students }\end{array}$ & 1106 & 379 & 288 & 2246 & 4019 & 4713 \\
Fee-paying students & 162 & 276 & 117 & 555 & 1110 & 1185 \\
Total & 1284 & 677 & 430 & 3090 & 5481 & 6296 \\
\hline
\end{tabular}


the characteristics of the total international student population in Hungary.

The questionnaire consisted of three main parts with special interest in the economic impacts of the target groups. The other two groups of questions focused on the role of international students in tourism and in the studentification processes. Three questions concentrated on the evaluation of the costsensitivity of international students within the studentification analysis, namely the cost of accommodation, cost of living and other costs (cost of services, cost of entertainment activities). The respondents were asked to evaluate the three types of costs by their satisfaction level on a scale (1 - not satisfied at all, 5 - totally satisfied). In the analysis, the average value was calculated for each city by the type of international students. Finally, the data were ranked and the differences were highlighted on two levels: (1) cities and (2) type of international students.

\section{Results}

\section{Accommodation costs}

How satisfied are you with the following attributes of the city: cost of accommodation? (1 - not satisfied at all, 5- totally satisfied).

Finding the right accommodation is one of the most sensitive issues for international students. It is important not only in terms of the location but also in terms of costs. The sensitivity results from the fact that compromise can be made in relation to place, but it is less probable to find compromise in terms of costs. Of course, income conditions largely determine the degree of satisfaction with prices. If the host university can provide high quality dormitory accommodation at a reasonable price, then that may set a limit to the costs in the city. This is, however, not typical of Budapest but more frequently observed in the other three cities with even significant differences between the universities.

Regarding the cost of accommodation, Pécs is the most popular of the four cities (Table 2). In the opinion of the fee-paying students it has similar evaluation as Budapest, while it got the highest values in comparison with the other cities. The position of Budapest seems to be the weakest in this field. The fact that Debrecen is lagging behind in this respect is due to the relatively strict evaluation of the fee-paying students.

The lowest points were given by the Stipendium Hungaricum students in each city most probably due to their higher representation in dormitories (and also due to the services offered by the dormitories). In their case, price sensitivity may also play a role, being more difficult to pay higher rents. Erasmus+ students are slightly more satisfied with this type of cost than the average.

\section{Living costs}

How satisfied are you with the following attributes of the city: cost of living? (1 - not satisfied at all, 5- totally satisfied)

The assessment of the cost of living is obviously related to individual needs, affordable costs, and the price level of supplies. The divergence of the preconceived notion about the host country and the reality may also play a role, and the comparison

Table 2. Evaluation of the accommodation costs

\begin{tabular}{lcccc}
\hline \multicolumn{1}{c}{ Accommodation } & Erasmus+ & Fee-paying & Stipendium Hungaricum & Average \\
\hline Budapest & 3.31 & 3.23 & 2.63 & 3.06 \\
Debrecen & 3.25 & 2.70 & 2.81 & 2.92 \\
Pécs & 4.31 & 3.20 & 2.92 & 3.48 \\
Szeged & 3.20 & 3.16 & 3.13 & 3.16 \\
Average & 3.52 & 3.07 & 2.87 & 3.15 \\
\hline
\end{tabular}


Table 3. Evaluation of living costs

\begin{tabular}{lcccc}
\hline \multicolumn{1}{c}{ Cost of living } & Erasmus+ & Fee-paying & Stipendium Hungaricum & Average \\
\hline Budapest & 3.80 & 3.64 & 3.24 & 3.56 \\
Debrecen & 3.93 & 3.11 & 3.22 & 3.42 \\
Pécs & 4.22 & 3.46 & 3.14 & 3.61 \\
Szeged & 3.64 & 3.55 & 3.43 & 3.54 \\
Average & 3.90 & 3.44 & 3.26 & 3.53 \\
\hline
\end{tabular}

of the price level with that of the sending country may also be an influencing factor.

The differences between student groups appear to be stable (Table 3). Erasmus+ students are the most satisfied (65\% "good", "very good"), followed by the fee-paying students (54.5\%) and the Stipendium Hungaricum students (41.6\%) are the last with the most critical assessment. The "medium/average" assessment is also the most frequent $(34.5 \%)$ in the case of the latter.

In the comparison on the level of cities, it is interesting that the fee-paying students gave the highest values in Budapest. The more cost-sensitive Stipendium Hungaricum students gave the lowest values in Pécs and found Szeged as better than the capital in this respect. In the case of Debrecen, values close to those of Budapest (and a better evaluation than that of Pécs) are not typical of the research on the whole. Overall, it may be established that the difference between the cities was the lowest in the case of the cost of living which has an equalising effect on the satisfaction with costs in total.

3.3. Other costs (cost of services, cost of entertainment activities)

How satisfied are you with the following attributes of the city: cost of services and cost of entertainment activities? (1 - not satisfied at all, 5- totally satisfied)

When evaluating the costs of services and entertainment activities, the culture of the sending country may be the most decisive factor, although being a university student, young age means the same needs for the group in many respects. However, it can be modified by social situation, income situation, or religious customs, etc. Without a more thorough understanding of these, only the general and known needs can be considered. At the same time, we cannot ignore the fact that the choice of a city is among students is greatly influenced by the opinions and evaluations of former students. Therefore, in addition to providing training and accommodation facilities, attention must be also paid to the accessibility and costs of services and entertainment activities. In terms of other costs, the Stipendium Hungaricum students gave the lowest values, and the credit mobility students gave the highest values. (Table 4)

Interestingly, in this respect, Budapest was preceded by at least one of the other cities in all student groups. For the Stipendium Hungaricum students Budapest seems to

Table 4. Evaluation of the „other costs”

\begin{tabular}{lcccc}
\hline \multicolumn{1}{c}{ Other costs } & Erasmus+ & Fee-paying & Stipendium Hungaricum & Average \\
\hline Budapest & 3.83 & 3.57 & 2.90 & 3.43 \\
Debrecen & 3.81 & 3.01 & 3.17 & 3.33 \\
Pécs & 4.10 & 3.43 & 3.13 & 3.55 \\
Szeged & 3.56 & 3.58 & 3.32 & 3.49 \\
Average & 3.83 & 3.40 & 3.13 & 3.45 \\
\hline
\end{tabular}




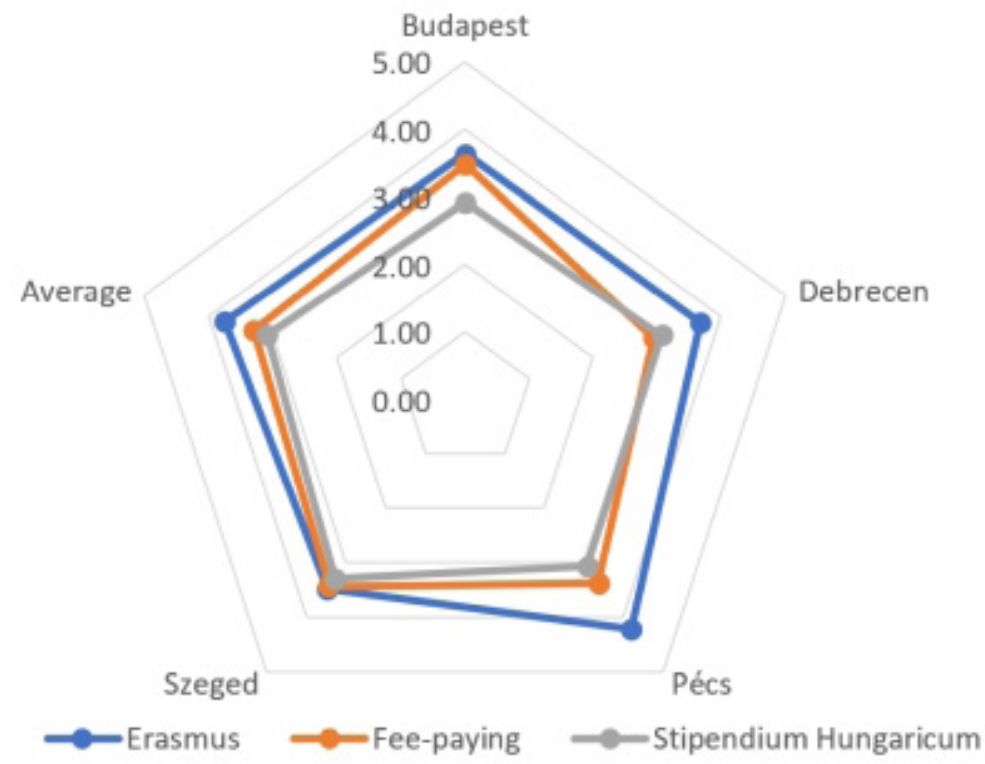

Fig. 2. Differences between the cities concerning the level of satisfaction with the total costs by types of international students

be the most expensive, while the fee-paying students in Debrecen are the most critical about the other costs. The values given by the Stipendium Hungaricum students are just above the average, while those of the feepaying students are considerably higher and the best averages can be observed in the case of the Erasmus+ students. The price and cost sensitivity of the Stipendium Hungaricum students is confirmed in relation to the other costs.

\section{Total costs}

The comparison of the cities based on the total costs results in finding the preference of Pécs with the most favourable positions, Szeged on the second place, Budapest on the third place and Debrecen on the fourth place. (Fig. 2)

There is an obvious difference between the cities on the basis of the satisfaction with the three types of costs broken down by the different groups of international students. Figure 1 reveals that the Erasmus+ students are the most satisfied with the highest relevance occurring in Pécs. In Debrecen the level of satisfaction among the Erasmus+ students also exceeds the satisfaction levels of the other two groups. The case of Budapest is interesting since the fee-paying students seem to be almost as satisfied with the accommodation, living and other costs as the Erasmus+ students. Szeged seems to be the most balanced since there the judgement of the costs is similar in all three groups.

In each category we can find the lowest level of satisfaction with costs in the case of the Stipendium Hungaricum students without significant deviation. The differences are more prominent in the two other groups although with differing patterns. Erasmus+ students are the most satisfied with the costs in all three categories and there is a positive deviation from the average thanks to the values in Pécs, while fee-paying students are relatively satisfied also but with negative deviations mostly produced by the values given by the students in Debrecen. (Fig. 3)

The ranking of the points given for each type of cost by the three groups of students reveals the overall highest satisfaction of the Erasmus+ students. The total values show that they are followed by the feepaying students and then the Stipendium 


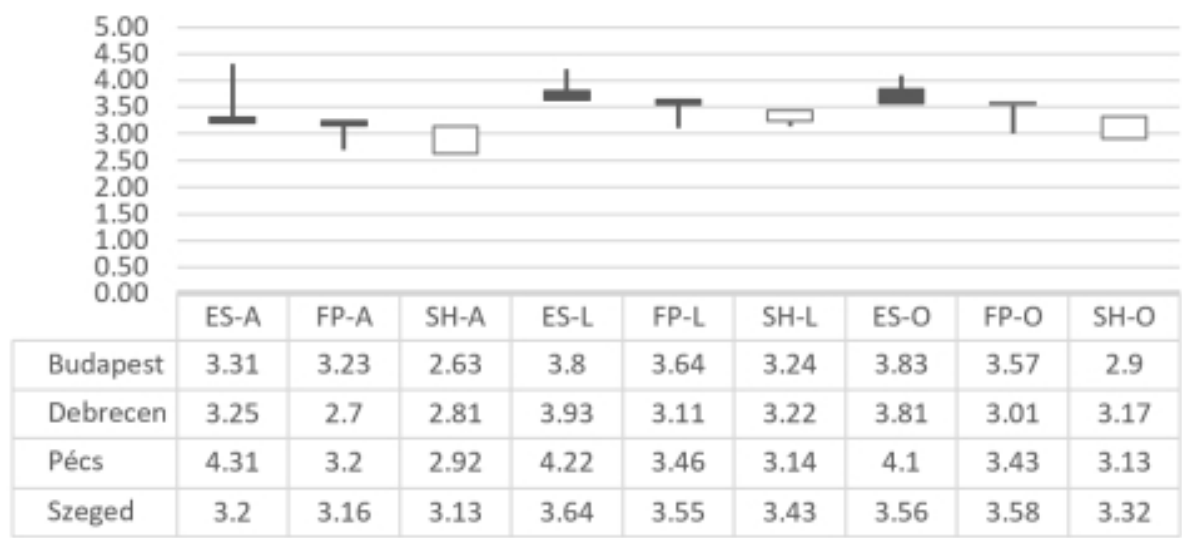

Fig. 3. Differences between the groups of international students concerning the level of satisfaction with costs by types of costs (cost-sensitivity of students) (Legend: ES - Erasmus+ students; FP - fee-paying students; SH - Stipendium Hungaricum students; A -accommodation; L - living; O - other)

Table 5. Cost-sensitivity ranking by cities and international students groups (Legend: ES - Erasmus+ students; FP - fee-paying students; SH - Stipendium Hungaricum students; A -accommodation;

$\mathrm{L}$ - living; $\mathrm{O}$ - other)

\begin{tabular}{lccccccccc}
\hline & ES-A & ES-L & ES-O & FP-A & FP-L & FP-O & SH-A & SH-L & SH-O \\
\hline Budapest & 1 & 1 & 1 & 2 & 2 & 2 & 3 & 3 & 3 \\
Debrecen & 1 & 1 & 1 & 3 & 3 & 3 & 2 & 2 & 2 \\
Pécs & 1 & 1 & 1 & 2 & 2 & 2 & 3 & 3 & 3 \\
Szeged & 1 & 1 & 2 & 2 & 2 & 1 & 3 & 3 & 3 \\
Total & 1 & 1 & 1 & 2 & 2 & 2 & 3 & 3 & 3 \\
\hline
\end{tabular}

Hungaricum students come on the third place in this respect. However, Debrecen differs from the other three cities because the Stipendium Hungaricum students are more satisfied with any of the occurring costs than the fee-paying students. (Table 5)

The cost sensitivity indicator of international students is derived from the absolute number of students in relation to the evaluation of the satisfaction with the three types of costs. To what extent do the costs of accommodation, living, services and entertainment activities influence the choice of the university/city for studying? Do the numbers of international students in the university cities reflect any kind of relationship in this respect?
We can confirm that cost-sensitivity exists but there are many other factors which finalised the decisions of foreign students. For instance, Budapest as the capital of the country is known and seen as a city of international significance. The accessibility, the economic position, cultural and social facilities make it a quality city. In the case of the universities outside Budapest, the three traditional university cities (Debrecen, Pécs and Szeged) attract the highest number of students primarily as a result of being recommended by friends or relatives, or through the representative offices all over the world. Taking all the above into consideration, it may be established that costs are relevant but not crucial elements in the choice of the universities or cities. 


\section{Discussion}

The questionnaire including questions related to the progress of the studentification process allowed us to form a picture of how the international students evaluate their spendings in the host country. Despite the different duration of stay, varying goals (credit, diploma) and diverse funding and financial resources, the three groups of students (Erasmus+, Stipendium Hungaricum and fee-paying students) were unanimous in many cases. The development of the areas they mentioned (often assessed) could be important elements and conditions for the "internationalisation" of higher education.

There are no extreme differences in terms of the costs related to being university student abroad when comparing the three rural university cities and Budapest. The cost of accommodation is found the worst with many evaluations below the average. Budapest and Debrecen received the lowest ratings in this respect. Regarding the cost of living, Budapest does not belong to the category of expensive cities.

The comparison of the host cities reveals that Budapest should be considered as a separate category being different from the other cities in many respects. Although, the assessment of the other three university centres (Pécs, Debrecen and Szeged) received similar evaluations (close average values) but some kind of order developed between them in which Szeged and Pécs are perhaps regarded in a little bit more favourable position than Debrecen. There is a lot to be improved to broaden the studentification process in these cities particularly (1) to strengthen the relationship between the cities and the universities, (2) to assess the needs and demands of students so to broaden the scale of available services, (3) to reorganise transport, (4) to create a more differentiated (mostly in terms of prices) accommodation especially close to the universities. The evaluations can certainly be considered useful in the sense that they help to identify those services which are problematic in any terms (price or quality).

\section{Acknowledgements}

This contribution presents results from the research coordinated by the Terra Graph Ltd. under the supervision of Dr. Zsuzsa M. Császár research leader. The research was carried out within the framework of the Stipendium Hungaricum Scholarship Programme supervised by the Ministry of Foreign Affairs and Trade and managed by the Tempus Public Foundation.

\section{References}

Berács, J. (2017): Hallgatói mobilitás, külföldi hallgatók a magyar felsőoktatásban. (Student mobility, international students in the Hungarian hgher education.) In: Magyar Felsőoktatás 2016, Budapest, NFKK, pp.57-63. ISSN: 1215-3990

Hubbard, P. (2008): Regulating the social impacts of studentification: a Loughborough case study. Environment and Planning A: Economy and Space. 40 (2): 323-341.

Hubbard, P. (2009): Geographies of studentification and purpose-built student accommodation: leading separate lives? Environment and Planning A: Economy and Space. 41 (8): 19031923.

M. Császár, Zs. et al. (2020): A befelé irányuló felsőoktatási mobilitás gazdasági hatásainak mérése. Vezetői összefoglaló. (Measuring the economic impacts of inward higher education mobility. executive Summary.) Tempus Public Foundation. Budapest. 36.

M. Császár, Zs., - Wusching, Á. T. (2016): A felsőoktatás nemzetköziesedésének hatása az egyetemvárosok fejlődésére egy pécsi esettanulmány tükrében. (Effect of the internationalization of higher education on the development of university towns: a case study from Pécs.) Földrajzi Közlemények. 140 (3): 245-257.

M, Császár Zs. - Teperics, K. - Wusching, Á. T. (2016): $\mathrm{Az}$ orvosi képzések nemzetközi hallgatói mobilitásának hatása a városgazdaságra. (The impact of international student mobility in medical training on the economy of cities.) In: Pajtókné, Tari I. - Tóth, A. (Eds.) Magyar Földrajzi Napok 2016: conference book. 8th Hungarian Geographers' Conference, 16th Geographer Doctoral Students Conference, Educational Methodology and Geography Teachers' Conference, Eger,Hungary. Magyar Földrajzi Társaság, Agria Geográfia Alapítvány, Eszterházy Károly Egyetem 2016. 129-139. 
Miklós, B. - Nagy Gy. - Karl M. J. (2018): A külföldi egyetemisták szabadidő-eltöltési és térhasználati mintázatai Szegeden. (Spatial patterns of leisure activities in Szeged.) KözépEurópai Közlemények 44 (1): 54-66.

Smith, P. D. (2005): "Studentification": the gentrification factory?. In: Atkinson, R. Bridge, G. (Eds.): Gentrification in a global context: the new urban colonialism. Housing and Society Series. Routledge. UK. 72-89.

Universities UK (2006): 'Studentification': a guide to opportunities, challenges and practices. Universities UK, London. 52.

FIR-OSAP database 